\title{
High-resolution profiles of iron, manganese, cobalt, cadmium, copper and zinc in the pore water of estuarine sediment
}

\author{
Z. Yang $\cdot$ W. Guo $\cdot$ Y. Fan $\cdot$ C. Lin $\cdot$ \\ M. He
}

Received: 26 October 2011/Revised: 12 January 2012 / Accepted: 25 September 2012/Published online: 30 October 2012

(C) CEERS, IAU 2012

\begin{abstract}
The remobilization of iron, manganese, cobalt, cadmium, copper and zinc in the pore water of estuarine sediment cores at Yingkou was assessed using diffusive equilibrium in thin films and diffusive gradients in thin films techniques. A relatively anoxic system $(+33.7$ to $-224.1 \mathrm{mV}$ ) in the sediment cores might cause the reductive release of iron, manganese and cobalt into pore water from the estuarine sediment. High-average concentrations of iron $\left(47.85 \mu \mathrm{g} \mathrm{ml}^{-1}\right)$ and manganese $\left(3.81 \mu \mathrm{g} \mathrm{ml}^{-1}\right)$ were observed using diffusive equilibrium in thin films on the sediment core, but the concentration of cobalt (18.02 $\mathrm{ng} \mathrm{ml}^{-1}$ ) was relatively low. A strong correlation between iron and cobalt was observed based on the vertical profiles of the metals. Manganese and iron were more readily released from the solid phase to the solution. The peak cobalt, copper and zinc concentrations were observed in the upper layer $(2-4 \mathrm{~cm})$ measured using diffusive gradients in thin films. However, the peak iron, manganese and cobalt concentrations were located in the deeper layer $(\geq 7 \mathrm{~cm}$ ). In addition, the concentration profiles measured using diffusive gradients in thin films of cobalt, copper and zinc were independent of the iron, manganese and cobalt distribution with respect to depth.
\end{abstract}

Keywords Diffusive equilibrium in thin films . Diffusive gradients in thin films - Remobilization . Sediment core $\cdot$ Trace metals

Z. Yang $(\bowtie) \cdot$ W. Guo · Y. Fan · C. Lin · M. He

State Key Laboratory of Water Environment Simulation,

School of Environment, Beijing Normal University,

Beijing 100875, China

e-mail: zfyang@bnu.edu.cn

\section{Introduction}

Estuarine sediment plays an important role as a sink for trace metals in rivers and occasionally acts as a source of metals to the sea. Due to the complicated interactions between the river and sea and the water chemical condition (such as variations in $\mathrm{pH}$ and redox potential) in estuaries, some metals, such as iron (Fe), manganese $(\mathrm{Mn})$, cobalt (Co), cadmium $(\mathrm{Cd})$, copper $(\mathrm{Cu})$ and zinc $(\mathrm{Zn})$, might frequently undergo deposition and resuspension at the interface of sediment and water (Fan et al. 2009; Stockdale et al. 2010; Sakellari et al. 2011). This phenomenon is similar to a "time bomb" for estuaries (Gao et al. 2006; Feng et al. 2011). Increasing human activities, such as industry and shipping, have greatly amplified this stress. Thus, it is urgent to better understand the behavior (mobilization and transport) of trace metals in estuarine sediments. Out of this context, the pore water is an important intermediary between the sediment and the overlying water; it plays a key role in the partitioning and diagenetic reaction of trace elements in the sediment (Metzger et al. 2007). Therefore, understanding the vertical profiles of trace metals in the pore water of core sediments in the estuarine depositional environment is necessary to secure the fragile equilibrium and ecological health of estuarine ecosystems.

The mobilization of trace metals in sediments is believed to be linked to the decomposition of organic matter and the associated reductive dissolution of $\mathrm{Fe}$ and Mn oxides (Shaw et al. 1990; Fones et al. 2004; TankereMuller et al. 2006). Previous studies have been carried out to infer fluxes through the sediment-water interface and to understand the role of diagenetic reactions, including the release or uptake of the metals within the sediments; they have used conventional techniques including centrifugation, squeezing, sippers and in situ dialysis peepers 
(Hesslein 1976; Watson and Frickers 1990; AleksanderKwaterczak and Helios-Rybicka 2009; Turner et al. 2010). However, these methods only achieve a relatively low spatial resolution ( $\mathrm{cm}$ scale). This is insufficient for studying geochemical processes, especially at the surface and sub-surface of the oxic and suboxic sediments. Microelectrodes and two- and three-dimensional arrays can show highly localized changes in oxygen concentration and $\mathrm{pH}$, and provide detailed profiles of trace metals. These techniques have greatly improved our understanding of redox coupling and the vertical layering of diagenetic processes of trace metals on a small scale (Taillefert et al. 2002).

With the development of diffusive equilibrium in thin films (DET) and diffusive gradients in thin films (DGT), high-resolution vertical or horizontal profiles of metals in sediment pore water can be assessed on a scale of millimeters or less (Davison and Zhang 1994; Zhang et al. 2002; Gao et al. 2006). Compared to the dialysis cell technique, DET can determine the pore water concentration in sediment quickly and directly (Davison et al. 1991; Harper et al. 1997). By vertically inserting a DGT probe into the sediments, the DGT technique directly measures the flux of metals from the sediment to the solution during deployment based on the mass transport of metals (Zhang et al. 2002; Fones et al. 2004; Stockdale et al. 2010). It uses a layer of Chelex cation exchange resin placed behind a layer of hydrogel that is covered with a $0.45-\mu \mathrm{m}$ membrane, through which metal ions are allowed to diffuse freely through (Sakellari et al. 2011). Using a DET or DGT technique, several studies have effectively revealed the behavior and role of diffusional transport and the (re)supply of metals, such as $\mathrm{Fe}, \mathrm{Mn}, \mathrm{Co}$, $\mathrm{Cd}, \mathrm{Cu}$ and $\mathrm{Zn}$, from sediments to solution in the sediments of the freshwater and marine depositional environments (Gao et al. 2006; Stockdale et al. 2010; Sakellari et al. 2011).

Here, a method combining DET and DGT was used to more completely understand the remobilization of the metals (e.g., $\mathrm{Fe}, \mathrm{Mn}, \mathrm{Co}, \mathrm{Cd}, \mathrm{Cu}$ and $\mathrm{Zn}$ ) in relation to $\mathrm{pH}$ and redox potential profiles while taking into account the different physicochemical characteristics at various depths along the sediment-water interface of the Yinkou estuary in Liaodong Bay in China. The results can provide in situ data of the vertical profiles and the release capacity of metals from sediments at a small scale. These methods have lower resolution, but can be applied as a type of control in practice. The study was carried out during 2006 at Yinkou estuary, China.

\section{Materials and methods}

Study site and sediment core collection

The study site was located in the Yingkou estuary in Liaodong Bay in China, which is affected by a number of anthropogenic factors, such as industrialization, urbanization and port activity and tidal currents. This region is located where the Daliaohe River enters the Bohai Sea. This river carries the combined pollution from industrial and domestic wastewater and the discharge from shipping and manufacturing (Fan et al. 2009). The bottom sediment in the estuarine tidal zone is intermittently inundated and exposed during the tidal cycle. During low tide (the depth of the overlying water was approximately $20 \mathrm{~cm}$ ), duplicates of undisturbed estuarine sediment cores were collected from the tidal zone at the Yingkou site (Fig. 1) using a free-fall corer sampler (manufactured by the Second Institute of Oceanography, State Oceanic Administration, China) with plastic tubes $(10 \mathrm{~cm}$ internal diameter and $50 \mathrm{~cm}$ long). The sampling operation was executed on June 2006 at the site $\left(\mathrm{N} 40^{\circ} 40.716^{\prime}, \mathrm{E} 122^{\circ} 14.373^{\prime}\right)$. After the sediment cores were retrieved, their top and bottom were sealed with rubber stoppers. Approximately $10 \mathrm{~cm}$ of the overlying water stayed inside. The tubes with sediment cores were kept upright and transported to the laboratory (State Key Laboratory of Water Environment Simulation, Beijing, China) rapidly under refrigeration.

\section{Measurement of redox potential and $\mathrm{pH}$ in the sediment} cores

In the laboratory, holes were opened on the tube wall at different sediment depths $(2.5 \mathrm{~cm}$ interval $)$ and $\mathrm{pH}$ and ORP electrodes were inserted horizontally. The small slits between the electrode wall and the tube wall were sealed. The redox potential (Eh) and $\mathrm{pH}$ were measured with combination platinum electrodes (Mettler Toledo/Pt4800) and combination glass electrodes (Mettler Toledo/Pt4800), respectively. For both electrodes, the reference electrode was $\mathrm{Ag} / \mathrm{AgCl},[\mathrm{KCl}]=3 \mathrm{M}$, having a potential of $220 \mathrm{mV}$ versus the standard hydrogen electrode.

\section{DET and DGT probe preparation and deployment}

The DET and DGT technique probe preparations and deployments were similar to those described by Zhang et al. (2002) and Gao et al. (2006). The diffusive gel (0.8 $\mathrm{mm}$ thickness), resin gel (0.4 mm thickness), and the DGT and DET probes were obtained from DGT Research Ltd., UK. The size of the DGT and DET probes was $180 \mathrm{~mm} \times 40 \mathrm{~mm}$, with a window of $150 \mathrm{~mm} \times 18 \mathrm{~mm}$ open to the aquatic system. After the gels were set, they were covered with a $0.45-\mu \mathrm{m}$ cellulose acetate filter (0.14 mm thickness, Millipore). Finally, the window plate was put on the top of the probe and all of the elements were gently pressed together. Before deployment of the DET probes, they were stored in Milli-Q water. While the DGT probes were stored at $4{ }^{\circ} \mathrm{C}$ in a closed plastic bag 
Fig. 1 The study area and sampling station in the catchment of the Daliao River watershed

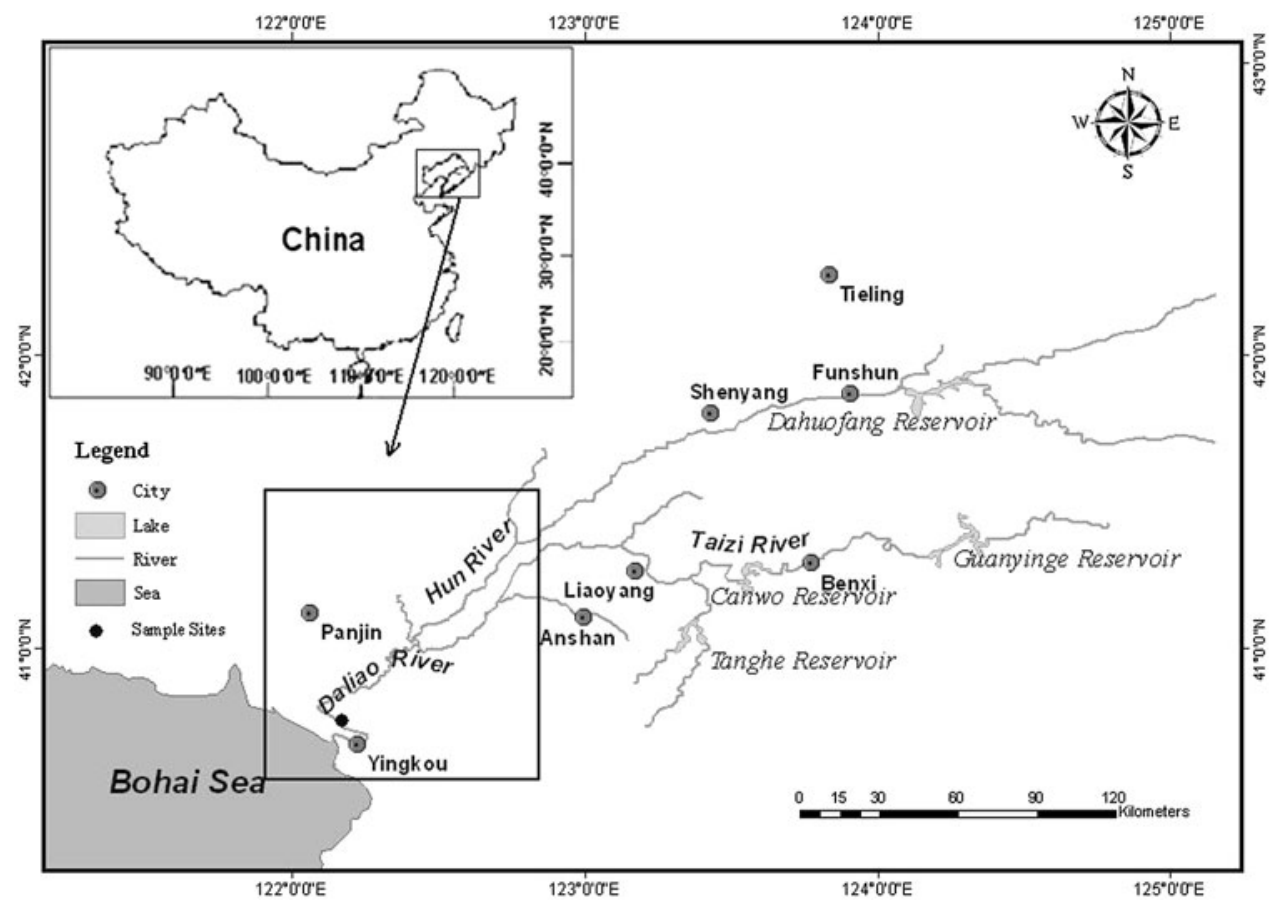

containing $1 \mathrm{ml}$ of $0.01 \mathrm{M}$ trace metal-free $\mathrm{NaCl}$ solution (5-10 g Chelex-100 were added to remove trace metals).

Before deployment, the entire DET gel assemblies were de-oxygenated by immersing them for $24 \mathrm{~h}$ in a container filled with Milli-Q water and bubbling with nitrogen, and the DGT probes were de-oxygenated for $24 \mathrm{~h}$ in a container filled with metal-free (using Chelex-100) $\mathrm{NaCl}$ $(0.1 \%)$ solution. Two DET and DGT probes, arranged back to back, were vertically inserted into the sediment cores to approximately $20 \mathrm{~cm}$ depth. The experiment was performed at $25 \pm 0.5^{\circ} \mathrm{C}$ for $24 \mathrm{~h}$. After $24 \mathrm{~h}$, the probes were retrieved from the sediment core.

In the laboratory, all gel manipulation was carried out in a laminar flow hood located in a clean room. The DET and DGT probes were opened, the filter and diffusive gel were removed and the resin gels including DET and DGT was cut into 5-mm intervals using a Plexiglas gel cutter, respectively. Each piece of DET gel was transferred into pre-weighed 2-ml tubes, weighed and eluted in $1 \mathrm{ml}$ of $1 \mathrm{M} \mathrm{HNO}_{3}$ for the determination of metals. Each DGT gel slice was eluted in $1 \mathrm{ml}$ of $1 \mathrm{M} \mathrm{HNO}_{3}$ for $24 \mathrm{~h}$, then diluted to $6 \mathrm{ml}$ for analysis. The DET and DGT blanks went through the same process, including probe preparation and deployment.

Sediment core section and pore water extraction

After Eh and $\mathrm{pH}$ measurement and the DET/DGT experiment, the sediment cores were sectioned inside a nitrogen flushed glove-bag. Approximately $100 \mathrm{~g}$ of fresh sediment from each segment was placed in a centrifuge tube. They were centrifuged for $30 \mathrm{~min}$ at 2,500 rpm, and the obtained pore waters were filtered through a $0.45-\mu \mathrm{m}$ cellulose acetate disposable filter, collected in a clean polyethylene tube, and acidified with $1 \% \mathrm{HNO}_{3}$.

Analysis

The concentrations of $\mathrm{Cd}, \mathrm{Co}, \mathrm{Cu}$ and $\mathrm{Zn}$ were determined using inductively coupled mass spectrometry (ICP-MS, X Series II, Thermo Ltd., USA). ${ }^{103} \mathrm{Rh}$ was used for internal calibration and a certified reference material (GSD-9) was supplied by the Institute of Geophysical and Geochemical Exploration of China. The concentrations of $\mathrm{Fe}$ and $\mathrm{Mn}$ were determined using inductively coupled plasma optical emission spectrometry (ICP-OES, IRIS Instrepid II, Thermo Ltd., USA) (Yang et al. 2009). Analytical quality control was carried out by measuring the same standard solution after every fifteenth sample. Blank DET and DGT for these metals are showed in Table 1. The measured concentrations other than DET for $\mathrm{Cd}, \mathrm{Cu}$ and $\mathrm{Zn}$ in the samples were well above the detection limits.

\section{Calculation procedures}

The metal concentration in the sediment and pore water interface was calculated using the method reported by Zhang et al. (2002). The flux of metals $(F)$ from sediment to the DGT or DET probe can be calculated using Eq. (1):

$F=M /(t A)$,

where $t$ is the deployment time (in seconds), $M$ is the mass of accumulated metals in the resin layer and $A$ is the area of 
Table 1 Blanks and concentration ranges observed with DET and DGT

DET and DGT results have been corrected for blank values

$d l$ detection limits (the value equal to three times the standard deviation of the blanks)

\begin{tabular}{lllll}
\hline Element & $\begin{array}{l}\text { DET blank } \\
\left(\mu \mathrm{g}^{-1}\right)\end{array}$ & $\begin{array}{l}\text { DET observed range } \\
\left(\mu \mathrm{g}^{-1}\right)\end{array}$ & $\begin{array}{l}\text { DGT blank } \\
\left(\mu \mathrm{g}^{-1}\right)\end{array}$ & $\begin{array}{l}\text { DGT observed range } \\
\left(\mu \mathrm{g} 1^{-1}\right)\end{array}$ \\
\hline $\mathrm{Cd}$ & $0.23 \pm 0.04$ & $<\mathrm{dl}$ & $0.02 \pm 0.005$ & $0.037-0.35$ \\
$\mathrm{Cu}$ & $5.80 \pm 2.12$ & $<\mathrm{dl}$ & $0.40 \pm 0.11$ & $1.25-5.14$ \\
$\mathrm{Zn}$ & $217 \pm 42$ & $<\mathrm{dl}$ & $5.57 \pm 1.18$ & $24.9-49.4$ \\
$\mathrm{Fe}$ & $570 \pm 125$ & $16,240-85,026$ & $6.0 \pm 2.18$ & $1,472-5,751$ \\
$\mathrm{Mn}$ & $67.8 \pm 4.20$ & $2,913-5,047$ & $0.45 \pm 0.27$ & $802-2,984$ \\
$\mathrm{Co}$ & $0.35 \pm 0.06$ & $9.08-32.2$ & $0.007 \pm 0.004$ & $0.20-0.60$ \\
\hline
\end{tabular}

the gel strip $\left(\right.$ in $\mathrm{cm}^{2}$ ). Assuming that the gel and membrane have the same diffusion coefficient, $D_{\mathrm{m}}$ (Davison and Zhang, 1994), this flux can be interpreted as the mean concentration, $C_{i}$, at the surface of the probe during deployment, according to Fick's law. Conservative flux properties lead to the following relationship:

$C_{i}=M \Delta g /\left(D_{\mathrm{m}} A t f_{\mathrm{e}}\right)$.

The mass of metal $(M)$ accumulated on the resin gel can be calculated from the concentration of metals in the elution solution $\left(C_{e}\right)$, according to Eq. (3).

$M=C_{\mathrm{e}}\left(V_{\mathrm{gel}}+V_{\text {acid }}\right) / f_{\mathrm{e}}$,

where $V_{\text {gel }}$ is the volume of the gel strip, $V_{\text {acid }}$ is the acid added for elution and $f_{\mathrm{e}}$ is the elution factor, which is 0.8 for all of the metals studied (Zhang and Davison 1995).

\section{Results and discussion}

Redox potential and $\mathrm{pH}$ profiles

The redox potential profile (Fig. 2) shows that the redox potential in the sediment core gradually decreased with increased depth. The value ranged from +33.7 to $-224.1 \mathrm{mV}$. The potential was positive $(>0 \mathrm{mV})$ at the water-sediment interface, then decreased continuously until a depth of approximately $12 \mathrm{~cm}$, which indicates that the core sediments of Yingkou are gradually changing from a suboxic to a completely reducing system (Vershinn and Rozanov 1982). The redox potential is particularly critical for characterizing the oxidation-reduction status of environmental systems and for interpreting redox-sensitive biogeochemical processes, such as degradation of organic matter, denitrification, and reductive dissolution of $\mathrm{Mn}$ and Fe oxides (Gao et al. 2006; Devesa-Rey et al. 2010; Sakellari et al. 2011). Therefore, the change in redox potential within the sediment core might result in a series of geochemical reactions and, thus, change the mobility and bioavailability of trace metals in the sediment core. The $\mathrm{pH}$ in the overlying water was over 8.0 and decreased to a constant value of approximately 6.9. It has also been demonstrated that acidic conditions $(\mathrm{pH}<7)$ contributed to the reduction of metals, such as $\mathrm{Fe}^{2+}$, under bacterial sulfate reduction (Yao and Millero 1996). Consequently, a combination of the Eh and $\mathrm{pH}$ would influence the remobilization of metals in the sediment cores.

Redox-sensitive metals ( $\mathrm{Fe}, \mathrm{Mn}$ and $\mathrm{Co}$ )

The concentration profiles of $\mathrm{Fe}, \mathrm{Mn}$ and Co that were measured using DET are shown in Fig. 3a. The DET concentrations measured in the core sediment ranged from 16.2 to $85.0 \mu \mathrm{g} \mathrm{ml}^{-1}$ for $\mathrm{Fe}$, from 2.9 to $5.1 \mu \mathrm{g} \mathrm{ml}^{-1}$ for $\mathrm{Mn}$ and from 9.1 to $32.2 \mu \mathrm{g} 1^{-1}$ for Co. The concentrations of $\mathrm{Fe}, \mathrm{Mn}$ and $\mathrm{Co}$ that were measured using DET increased from the sediment-water interface down to $10.5 \mathrm{~cm}$ and decreased from 10.5 to $12 \mathrm{~cm}$. There is an excellent comparability between $\mathrm{Fe}, \mathrm{Mn}$ and $\mathrm{Co}$, with maxima occurring at the same depths (Fig. 3a). These figures may suggest that the factors influencing the release of $\mathrm{Fe}, \mathrm{Mn}$ and $\mathrm{Co}$ are similar. The geochemical similarity and remarkably close relationships between $\mathrm{Fe}, \mathrm{Mn}$ and $\mathrm{Co}$ have been documented in the water column (Taillefert et al. 2002; Gao et al. 2006). The relatively low redox and $\mathrm{pH}$ may be the major factors determining the maximum metal concentrations at deeper sediment layers $(10-11 \mathrm{~cm})$ (Figs. 2, 3a) (Davutluoglu et al. 2011). The redox potential decreased sharply from the surface down to $12 \mathrm{~cm}$, which might lead to increased concentrations of $\mathrm{Fe}$ (II), Mn(II) and $\mathrm{Co}$ (II) (Gao et al. 2006). After oxygen is depleted near the water-sediment interface, other oxidants [especially nitrate, $\mathrm{Fe}(\mathrm{III})$ and $\mathrm{Mn}(\mathrm{IV})]$ become involved in the diagenesis of organic matter. Thus, the reduced soluble forms of $\mathrm{Fe}(\mathrm{II}), \mathrm{Mn}$ (II) and $\mathrm{Co}(\mathrm{II})$ become the dominant forms in the deeper layer.

The concentration profiles of $\mathrm{Fe}, \mathrm{Mn}$ and Co measured by DGT are shown in Fig. 3b. The DGT concentrations measured in the core sediment ranged from 1.5 to $5.8 \mu \mathrm{g} \mathrm{mL}^{-1}$ for $\mathrm{Fe}$, from 0.8 to $3.0 \mu \mathrm{g} \mathrm{mL}^{-1}$ for $\mathrm{Mn}$ and from 0.2 to $0.6 \mu \mathrm{g} \mathrm{L}^{-1}$ for Co. In the upper sediment $(0-8 \mathrm{~cm})$, the $\mathrm{Fe}, \mathrm{Mn}$ and Co DGT profiles followed the same trend. However, in the deeper $(9-12 \mathrm{~cm})$ sediment (Fig. 3b), the metals' vertical profiles are significantly different. The maximum concentrations of $\mathrm{Fe}, \mathrm{Mn}$ and $\mathrm{Co}$ measured using DGT occurred at approximately 11.5, 7.0 
Fig. 2 Redox potential (a) and $\mathrm{pH}$ (b) profiles in the pore water of sediment cores
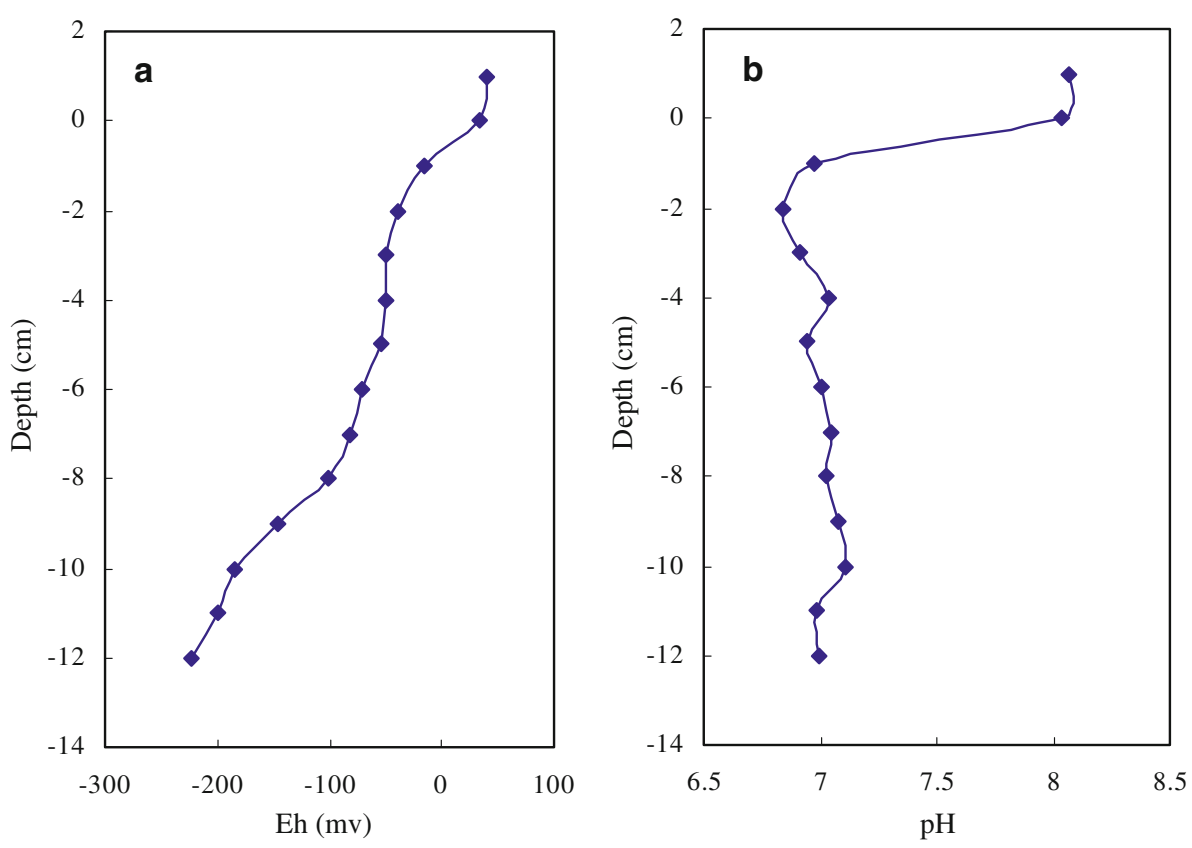

and $9.5 \mathrm{~cm}$ depth, respectively. A suboxic or reducing environment contributed to the reduction of metals, such as $\mathrm{Fe}, \mathrm{Mn}$ and $\mathrm{Co}$. They are then mobilized to the dissolved phase, thus the characteristic peak concentration for these metals typically occurred in the deeper layer of the sediment cores (Sakellari et al. 2011). The Mn and Co concentrations that were measured using DGT increased at a shallower depth than that of $\mathrm{Fe}$, which might reflect the more ready reductive dissolution of $\mathrm{Mn}$ and Co oxyhydroxides (Canfield et al. 1993). Similar behavior for Mn and Co was also noted in freshwater sediments by Zhang et al. (2002).

The concentrations of $\mathrm{Fe}, \mathrm{Mn}$ and $\mathrm{Co}$ obtained with the DGT were significantly lower than those obtained using the DET; and the varied magnitude of Fe, Mn and Co obtained with the DGT are greater than those obtained using the DET, especially for Fe (Fig. 3). This difference between the DET and DGT data might be due to the following reasons: (1) the sampling of different types of species (equilibrium versus diffusion condition) and (2) a sedimentary resupply process for DGT in which sediment partially compensates for the depletion of pore water concentrations of metals such as $\mathrm{Fe}, \mathrm{Mn}$ and $\mathrm{Co}$ that was induced by DGT deployment (Fones et al. 2001, 2004; Zhang et al. 2002; Tankere-Muller et al. 2006).

Features of $\mathrm{Cd}, \mathrm{Cu}$, and $\mathrm{Zn}$

Compared to redox-sensitive metals, such as $\mathrm{Fe}, \mathrm{Mn}$ and $\mathrm{Co}$, other trace metals, such as $\mathrm{Cd}, \mathrm{Cu}$ and $\mathrm{Zn}$, were not measurable with the DET technique due to high blank values. The concentration profiles of $\mathrm{Cd}, \mathrm{Cu}$ and $\mathrm{Zn}$ that were measured by DGT are shown in Fig. 4. The DGT concentrations measured in the core sediment ranged from 0.04 to $0.24 \mu \mathrm{g} \mathrm{l}^{-1}$ for $\mathrm{Cd}$, from 2.2 to $5.1 \mu \mathrm{g} \mathrm{l}^{-1}$ for $\mathrm{Cu}$ and from 0.02 to $0.06 \mu \mathrm{g} \mathrm{ml}^{-1}$ for $\mathrm{Zn}$. The DGT profiles of $\mathrm{Cd}, \mathrm{Cu}$ and $\mathrm{Zn}$ followed the same trend (Fig. 4), which might be attributed to their similar geochemical features (Fones et al. 2004).

The DGT-measured concentrations of $\mathrm{Cd}, \mathrm{Cu}$ and $\mathrm{Zn}$ are greatest near the sediment surface $(2-4 \mathrm{~cm})$ and decrease as the depth increases, which differs from the $\mathrm{Fe}, \mathrm{Mn}$ and Co profiles. Concentration maxima near the sediment surface have been observed previously in pore waters obtained from marine sediments by centrifugation and filtration (Shaw et al. 1990) and from freshwater sediments by in situ dialysis (Gao et al. 2006). The location of the $\mathrm{Cd}, \mathrm{Cu}$ and $\mathrm{Zn}$ peak was above that of $\mathrm{Fe}, \mathrm{Mn}$ and $\mathrm{Co}$, which may be due to the following reasons: (1) the concentrations of dissolved $\mathrm{Fe}, \mathrm{Mn}$ and Co were relatively low in the upper sediment (oxic environment) for the formation of their oxidized solid phase (Haese 2006); (2) rapid degradation and dissolution of organic matter reaching the sediment surface (Tankere-Muller et al. 2006); and (3) desorption from particulates due to gradual change in the $\mathrm{pH}$ value (Teasdale et al. 2003). Moreover, these buried sediments are likely to contain appreciable $\mathrm{FeS}, \mathrm{Cd}, \mathrm{Cu}$ and $\mathrm{Zn}$ levels, which could be removed from a solution by displacement or lattice substitution reactions (DiToro et al. 1990). Thus, the different metal profiles observed in the fine-scale structure probably reflect different sources and transport processes. 

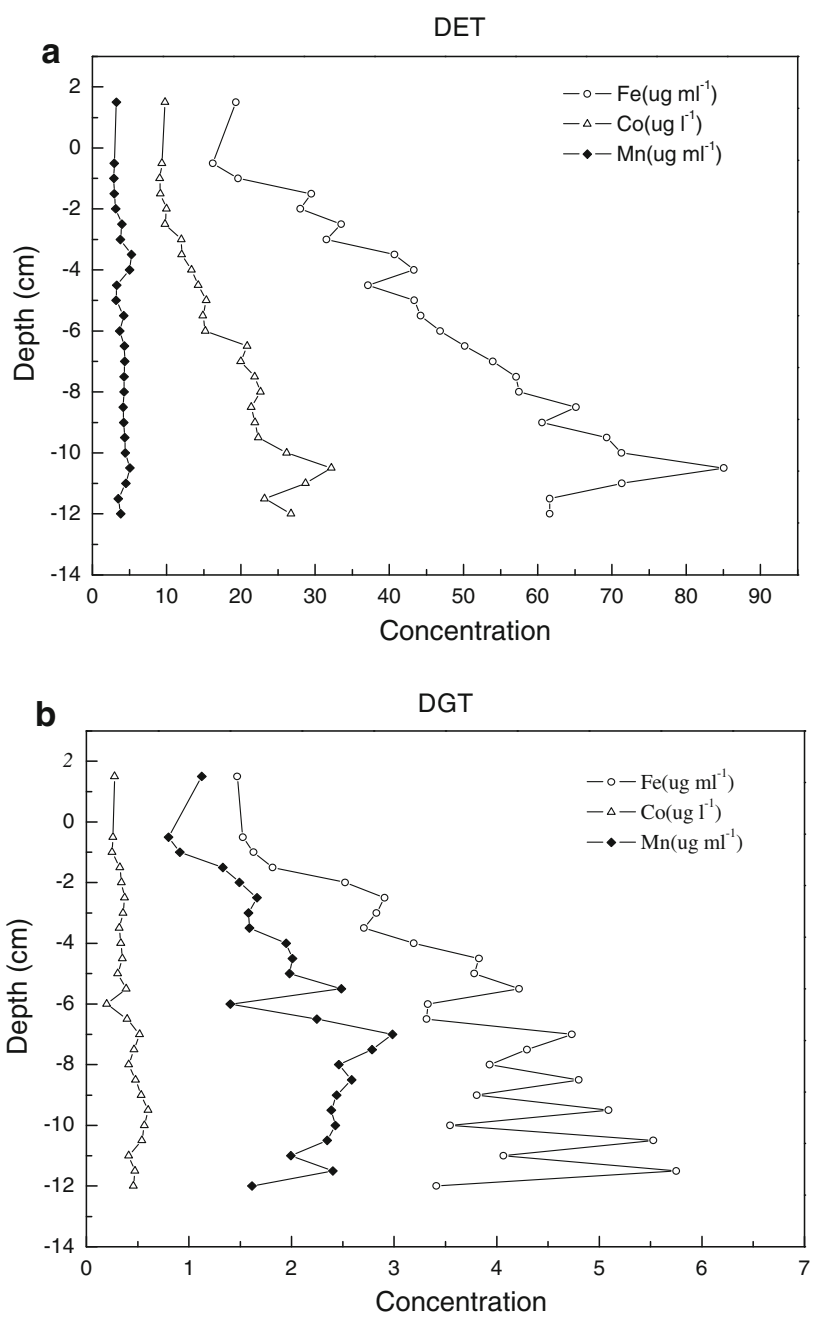

Fig. 3 DET (a) and DGT (b) depth profiles of Fe, Mn and Co in the pore water of sediment cores

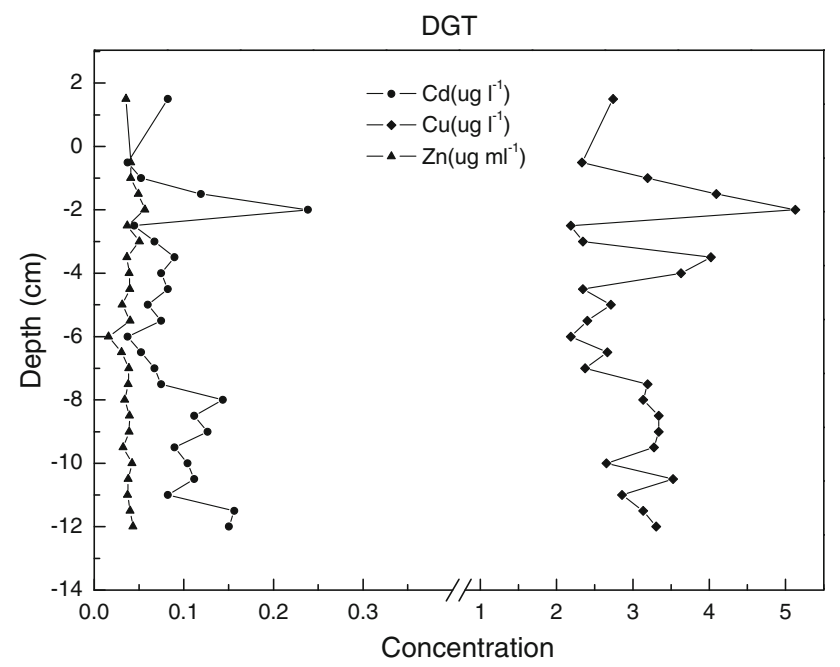

Fig. 4 DGT depth profiles of $\mathrm{Cd}, \mathrm{Cu}$ and $\mathrm{Zn}$ in the pore water of sediment cores
Table $2 R$ value obtained from Yinkou sediment core

\begin{tabular}{lllll}
\hline \multirow{2}{*}{$\begin{array}{l}\text { Trace } \\
\text { metal }\end{array}$} & \multicolumn{2}{l}{ Average concentration $\left(\mathrm{ng} \mathrm{m}^{-1}\right)$} & & $R$ value DGT/ \\
\cline { 2 - 3 } & DET & Centrifugation & DGT & \\
\hline $\mathrm{Cd}$ & - & 0.66 & 0.10 & 0.15 \\
$\mathrm{Cu}$ & - & 29 & 3.44 & 0.12 \\
$\mathrm{Zn}$ & - & 359 & 38.2 & 0.11 \\
$\mathrm{Fe}$ & 46,709 & 6,639 & 3,521 & $0.53(0.08)$ \\
$\mathrm{Mn}$ & 3,955 & 3,042 & 1,960 & $0.64(0.50)$ \\
$\mathrm{Co}$ & 17.7 & 5.38 & 0.40 & $0.07(0.02)$ \\
\hline
\end{tabular}

Metal supply from sediments to pore water

A comparison of measurements made with DGT and DET or conventional techniques in sediments can reflect a sedimentary supply process (Krom et al. 2002; Metzger et al. 2007). The ratio of DGT to DET or DGT to centrifugation ( $R$ : DGT/DET or DGT/centrifugation, with $0<R<1$ ) has been used to assess the supply from the solid phase to solution (Harper et al. 1998). However, comparisons between the centrifugation technique and the DGT technique should be carried out with caution. DGT measures the localized interfacial concentration (which is depleted due to metal uptake by the DGT probe) in a very small volume of sediment adjacent to the DGT probe, whereas classical techniques measure bulk pore water concentrations averaged across a much larger (100-1,000 times larger) volume of sediment (Gao et al. 2006). In our case, the ratio $R$ can be described as the average metal concentration from DGT divided by the average metal concentration from DET or centrifugation (Table 2). The $R$ values (based on DGT/centrifugation unless otherwise indicated) for trace elements were in accordance with the following order: $\mathrm{Mn}(0.64)>\mathrm{Fe}(0.53)>\mathrm{Mn}(0.50 \mathrm{DGT} /$ DET $)>\mathrm{Cd}(0.15)>\mathrm{Cu}(0.12)>\mathrm{Zn}(0.11)>\mathrm{Fe}(0.08$ DGT/DET $)>$ Co $(0.07)>$ Co $(0.02$ DGT/DET $)$. The differences between centrifugation or DET and DGT can be attribute to some reasons such as the pore size of the gels (20-30 nm for DET and 3-5 nm for DGT), the competition between the DGT resin and complexing ligands when metal complexes are abundant, depletion of the pore water during DGT sampling and so on (Gao et al. 2006). Compared with other trace metals, $\mathrm{Mn}$ and $\mathrm{Fe}$ were more readily released from the solid phase to solution, according to the $R$ value. The close $R$ values of $\mathrm{Cd}, \mathrm{Cu}$ and $\mathrm{Zn}$ suggest similar release characteristics of labile $\mathrm{Cd}, \mathrm{Cu}$ and $\mathrm{Zn}$. There is a considerable difference between the $R$ values obtained using DET probes and centrifugation for Fe. The most plausible reason to explain these differences is that despite the use of the oxygen-free glove-bag for handling 
Table 3 Correlation analysis of DGT-measured concentrations

\begin{tabular}{llllllr}
\hline Metals & $\mathrm{Fe}$ & $\mathrm{Mn}$ & $\mathrm{Co}$ & $\mathrm{Cd}$ & $\mathrm{Cu}$ & $\mathrm{Zn}$ \\
\hline $\mathrm{Fe}$ & 1 & $0.738^{* *}$ & $0.854^{* *}$ & 0.187 & -0.071 & -0.231 \\
Sig.(2- & & 0 & 0 & 0.359 & 0.731 & 0.257 \\
$\quad$ tailed) & & & & & & \\
Mn & & 1 & $0.787 * *$ & 0.33 & 0.096 & 0.131 \\
Sig.(2- & & 0 & 0.1 & 0.642 & 0.524 \\
$\quad$ tailed) & & & & & \\
Co & & & 1 & 0.151 & -0.073 & -0.133 \\
Sig.(2- & & & 0.461 & 0.723 & 0.519 \\
$\quad$ tailed) & & & & & \\
Cd & & & & 1 & $0.747 * *$ & $0.550^{* *}$ \\
Sig.(2- & & & & 0 & 0.004 \\
$\quad$ tailed) & & & & & $0.487 *$ \\
Cu & & & & & 0.012 \\
Sig.(2- & & & & & 1 \\
$\quad$ tailed) & & & & & \\
Zn & & & & & & \\
\hline
\end{tabular}

** Correlation is significant at the 0.01 level (2-tailed)

* Correlation is significant at the 0.05 level (2-tailed)

the cores during sectioning and centrifugation, oxygen still may come into contact with the pore water, which may oxidize the dissolved Fe(II) into solid Fe(III) (Zhang et al. 2002; Gao et al. 2006).

The correlation analysis of concentrations measured by DGT

A correlation analysis of metal concentrations measured by DGT is presented in Table 3. A good correlation was observed within two group metals, respectively: (1) redoxsensitive metals such as $\mathrm{Fe}, \mathrm{Mn}$ and $\mathrm{Co}(r \geq 0.738$, $p<0.01, n=26$ ) and (2) other trace metals such as Cd, $\mathrm{Cu}$ and $\mathrm{Zn}(r \geq 0.487, p<0.05, n=26)$. This result was in accordance with the results of Figs. 3 and 4. Compared with the DGT values for Mn, the DGT values for Fe and Co had better correlation $(r=0.854, p<0.01, n=26)$ in varied trends of the metal concentrations according to depth. This result suggests that a similar mechanism may operate for the two metals' geochemical behavior (Shuttleworth et al. 1999; Stockdale et al. 2010): (1) the reductive remobilization of the two metals may require very similar conditions and may occur simultaneously but independently; (2) Co may be incorporated into Fe and $\mathrm{Mn}$ oxyhydroxides and then released as they are reductively dissolved (but $\mathrm{Mn}$ was more readily reducible than $\mathrm{Fe}$ ); and (3) Co may be released from the organic matter, which is decomposed to supply electrons to the oxyhydroxides.

Compared with the DGT values of $\mathrm{Zn}$, the DGT values of $\mathrm{Cd}$ and $\mathrm{Cu}$ had better correlation $(r=0.747, p<0.01$, $n=26)$ in varied trends of the metal concentrations according to depth. This observation may suggest that the two metals have more similar remobilization features (Fig. 4). $\mathrm{Cd}, \mathrm{Cu}$ and $\mathrm{Zn}$ were significantly negatively correlated (or showed no correlation) with $\mathrm{Fe}, \mathrm{Mn}$ and $\mathrm{Co}$. This correlation may suggest that as the redox decreased, the remobilization of $\mathrm{Fe}, \mathrm{Mn}$ and Co increased, whereas as redox increased, the concentrations of $\mathrm{Cd}, \mathrm{Cu}$ and $\mathrm{Zn}$ ions in pore water also increased. A similar result was also observed in the research of Fones et al. (2004). Dissolved $\mathrm{Cd}, \mathrm{Cu}$ and $\mathrm{Zn}$ can be adsorbed into metal-oxide surfaces $\left(\mathrm{Fe}(\mathrm{OH})_{3}, \mathrm{FeOOH}, \mathrm{MnOx}\right.$, etc.) (Gerringa 1991; Swedlund et al. 2003), but the subsequent acidification of pore water with a decreasing $\mathrm{pH}$ can lead to desorption and the mobilization of metals out of these oxides. Thus, the remobilization of $\mathrm{Cd}, \mathrm{Cu}$ and $\mathrm{Zn}$ may also stem from dissimilative reduction-bearing metal oxides that are engaged in organic matter mineralization. In addition, the dissolved $\mathrm{Cd}, \mathrm{Cu}$ and $\mathrm{Zn}$ may diffuse upward (to reach the water column) and downward (into the anoxic sediment) where these metals can be immobilized by precipitation as sulfides, co-precipitation with $\mathrm{FeS}$ or adsorption onto $\mathrm{FeS}$ surfaces (Morse 1994; Gobeil et al. 1997).

\section{Conclusion}

In this study, both DET and DGT techniques were applied to generate high-resolution profiles of the total dissolved (DET) and labile (DGT) $\mathrm{Fe}, \mathrm{Mn}, \mathrm{Co}, \mathrm{Cd}, \mathrm{Cu}$ and $\mathrm{Zn}$ in estuarine sediment core pore water. The DET/DGT-measured concentrations of $\mathrm{Fe}, \mathrm{Mn}$ and $\mathrm{Co}$ were greatest in the deeper layers of the core sediment $(>7 \mathrm{~cm})$, but the DGT-measured concentrations of $\mathrm{Cd}, \mathrm{Cu}$ and $\mathrm{Zn}$ were greatest near the sediment surface $(2-4 \mathrm{~cm})$, which might be due to the decomposition of organic matter, the impact of the redox and $\mathrm{pH}$ variation and the differences in the sources and transport processes for the different metals. The correlation analysis of metals using DGT confirmed the difference at the sedimentwater interface between the remobilization of reductionsensitive metals, such as $\mathrm{Fe}, \mathrm{Mn}$ and $\mathrm{Co}$, as well as other trace metals, such as $\mathrm{Cd}, \mathrm{Cu}$ and $\mathrm{Zn}$. The concentrations of $\mathrm{Fe}, \mathrm{Mn}$ and Co that were measured using DGT were significantly lower than those of metals that were measured using DET, reflecting that sedimentary resupply processes partially compensate for the depletion of pore water metal concentrations induced by DGT deployment. According to the analysis of the characteristics of metal supply from the solid phase ( $R$ value), Mn and Fe were more readily released from the solid phase to solution, and $\mathrm{Cd}, \mathrm{Cu}$ and $\mathrm{Zn}$ had similar release characteristics.

Acknowledgments The study was supported by the National Basic Research Program of China (973 Program, 2010CB429003) and National Natural Science Foundation of China (Grant No. 40971058). 


\section{References}

Aleksander-Kwaterczak U, Helios-Rybicka E (2009) Contaminated sediments as a potential source of $\mathrm{Zn}, \mathrm{Pb}$, and $\mathrm{Cd}$ for a river system in the historical metalliferous ore mining and smelting industry area of south Poland. J Soils Sediments 9:13-22

Canfield DE, Thamdrup B, Hansen JW (1993) The anaerobic degradation of organic matter in Danish coastal sediments: iron reduction, manganese reduction and sulfate reduction. Geochim Cosmochim Acta 57:3867-3883

Davison W, Zhang H (1994) In situ speciation measurements of trace components in natural waters using thin film technique. Nature 367:546-548

Davison W, Grime GW, Morgen JAW, Clarke K (1991) Distribution of dissolved iron in sediment pore waters at submillimetre resolution. Nature 352:323-324

Davutluoglu OI, Seckin G, Ersu CB, Yilmaz T, Sari B (2011) Heavy metal content and distribution in surface sediments of the Seyhan River, Turkey. J Environ Manage 92:2250-2259

Devesa-Rey R, Díaz-Fierros F, Barral MT (2010) Trace metals in river bed sediments: an assessment of their partitioning and bioavailability by using multivariate exploratory analysis. J Environ Manage 91:2471-2477

DiToro DM, Mahony JD, Hansen DJ, Scott KJ, Hicks MB, Mayr SM, Redmond MS (1990) Toxicity of cadmium in sediments: the role of acid volatile sulphide. Environ Toxicol Chem 9:1487-1502

Fan YH, Lin CY, He MC, Yang ZF (2009) Enrichment and chemical fraction of copper and zinc in the sediments of the Daliao river system, China. Soil Sediment Contam 18:688-701

Feng H, Jiang HY, Gao WS, Weinstein MP, Zhang QF, Zhang WG, Yu LZ, Yuan DK, Tao JH (2011) Metal contamination in sediments of the western Bohai Bay and adjacent estuaries, China. J Environ Manage 92:1185-1197

Fones GR, Davison W, Holby O, Jorgensen BB, Thamdrup B (2001) High-resolution metal gradients measured by in situ DGT/DET deployment in Black Sea sediments using an autonomous benthic lander. Limnol Oceanogr 46:982-988

Fones GR, Davison W, Hamilton-Taylor J (2004) The fine scale remobilisation of metals in the surface sediment of the North East Atlantic. Cont Shelf Res 24:1485-1504

Gao Y, Leermakers M, Gabelle C, Divis P, Billon G, Ouddane B, Fischer J-C, Wartel M, Baeyens W (2006) High-resolution profiles of trace metals in the pore waters of riverine sediment assessed by DET and DGT. Sci Total Environ 362:266-277

Gerringa LJA (1991) Mobility of $\mathrm{Cu}, \mathrm{Cd}, \mathrm{Ni}, \mathrm{Pb}, \mathrm{Zn}, \mathrm{Fe}$ and $\mathrm{Mn}$ in marine sediment slurries under anaerobic conditions and at $20 \%$ air saturation. Neth J Sea Res 27:145-156

Gobeil C, Macdonald RW, Sundby B (1997) Diagenetic separation of cadmium and manganese in suboxic continental margin sediments. Geochim Cosmochim Acta 61:4647-4654

Haese RR (2006) The reactivity of iron. In: Schulz HD, Zabel M (eds) Marine geochemistry. Springer, Berlin Heidelberg, pp 241-270

Harper MP, Davison W, Tych W (1997) Temporal, spatial, and resolution constraints for in situ sampling devices using diffusional equilibration: dialysis and DET. Environ Sci Technol 31:3110-3119

Harper MP, Davison W, Zhang H, Tych W (1998) Kinetics of metal exchange between solids and solutions in sediments and soils interpreted from DGT measured fluxes. Geochim Cosmochim Acta 62:2757-2770

Hesslein RH (1976) An in situ sampler for close interval pore water studies. Limnol Oceanogr 21:912-915
Krom MD, Mortimer RJG, Poulton SW, Haies PJ, Davies IM, Davison W, Zhang H (2002) In situ determination of dissolved iron production in recent marine sediments. Aquat Sci 64:282-291

Metzger E, Simonucci C, Viollier E, Sarazin G, Prevot F, ElbazPoulichet F, Seidel JL, Jezequel D (2007) Influence of diagenetic processes in Thau lagoon on cadmium behavior and benthic fluxes. Estuar Coast Shelf Sci 72:497-510

Morse JW (1994) Interactions of trace metals with authigenic sulfide minerals: implications for their bioavailability. Mar Chem $46: 1-6$

Sakellari A, Plavsic M, Karavoltsos S, Dassenakis M, Scoullos M (2011) Assessment of copper, cadmium and zinc remobilization in Mediterranean marine coastal sediments. Estuar Coast Shelf Sci 91:1-12

Shaw TJ, Gieskes JM, Jahnke RA (1990) Early diagenesis in differing depositional environments: the response of transition metals in pore water. Geochim Cosmochim Acta 54:1233-1246

Shuttleworth SM, Davison W, Hamilton-Taylor J (1999) Two dimensional and fine structure in the concentrations of iron and manganese in sediment pore-waters. Environ Sci Technol 33:4169-4175

Stockdale A, Davison W, Zhang H, Hamilton-Taylor J (2010) The association of cobalt with iron and manganese (oxyhydr)oxides in marine sediment. Aquat Geochem 16:575-585

Swedlund PJ, Webster JG, Miskelly GM (2003) The effect of $\mathrm{SO}_{4}$ on the ferrihydrite adsorption of $\mathrm{Co}, \mathrm{Pb}$ and $\mathrm{Cd}$ : ternary complexes and site heterogeneity. Appl Geochem 18:1671-1689

Taillefert M, MacGregor B, Gaillard JF, Lienemann CP, Perret D, Stahl D (2002) Evidence for a dynamic cycle between Mn and Co in the water column of a stratified lake. Environ Sci Technol $36: 468-476$

Tankere-Muller S, Zhang H, Davison W, Finke N, Larsen O, Stahl H, Glud RN (2006) Fine scale remobilisation of $\mathrm{Fe}, \mathrm{Mn}, \mathrm{Co} ., \mathrm{Ni}, \mathrm{Cu}$ and $\mathrm{Cd}$ in contaminated marine sediment. Mar Chem 28:285300

Teasdale PR, Apte SC, Ford PW, Batley GE, Koehnken L (2003) Geochemical cycling and speciation of copper in waters and sediments of Macquarie Harbour, Western Tasmania. Estuar Coast Shelf Sci 57:475-487

Turner A, Cabon A, Glegg GA, Fisher AS (2010) Sediment-water interactions of thallium under simulated estuarine conditions. Geochim Cosmochim Acta 74:6779-6787

Vershinn AV, Rozanov AG (1982) On the problem of Eh measurement by the Pt electrode and estimation of oxidation reduction conditions in marine media. Geokhimiya 1:121-128

Watson PG, Frickers TE (1990) A multilevel, in situ pore water sampler for use in intertidal sediments and laboratory microcosms. Limnol Oceanogr 35:1381-1389

Yang ZF, Wang Y, Shen ZY, Niu JF, Tang ZW (2009) Distribution and speciation of heavy metals in sediments from the mainstream, tributaries, and lakes of the Yangtze River catchment of Wuhan, China. J Hazard Mater 166:1186-1194

Yao W, Millero FJ (1996) Oxidation of hydrogen sulfide by hydrous $\mathrm{Fe}(\mathrm{III})$ oxides in seawater. Mar Chem 52:1-16

Zhang H, Davison W (1995) Performance characteristics of diffusion gradients in thin-films for the in situ measurement of trace metals in aqueous solution. Anal Chem 67:3391-3400

Zhang H, Davison W, Mortimer RJG, Krom MD, Hayes PJ, Davies IM (2002) Localised remobilization of metals in amarine sediment. Sci Total Environ 296:175-187 